\title{
Dairy Management Practices Associated with Incidence Rate of Clinical Mastitis in Low Somatic Cell Score Herds in France
}

\author{
J. Barnouin, ${ }^{1}$ S. Bord, ${ }^{1}$ S. Bazin, ${ }^{2}$ and $M$. Chassagne ${ }^{1}$ \\ ${ }^{1}$ Animal Epidemiology Research Unit, INRA, 63122 Saint Genès Champanelle, France \\ ${ }^{2}$ France Contrôle Laitier, 167 rue du Chevaleret, 75013 Paris, France
}

\begin{abstract}
An epidemiological prospective study was carried out in French dairy herds with Holstein, Montbéliarde, or Normande cows and with low herd somatic cell scores. The objective was to identify dairy management practices associated with herd incidence rate of clinical mastitis. The studied herds were selected on a national basis, clinical cases were recorded through a standardized system, and a stable dairy management system existed. In the surveyed herds, mean milk yield was $7420 \mathrm{~kg} / \mathrm{cow}$ per yr and mean milk somatic cell score was $2.04(132,000$ cells $/ \mathrm{mL})$. Overdispersion Poisson models were performed to investigate risk factors for mastitis incidence rate. From the final model, the herds with the following characteristics had lower incidence rates of clinical mastitis: 1 ) culling of cows with more than 3 cases of clinical mastitis within a lactation; 2) more than 2 person-years assigned to dairy herd management; 3) balanced concentrate in the cow basal diet. Moreover, herds with the following characteristics had higher incidence rates of clinical mastitis: 1) milking cows loose-housed in a straw yard; 2) no mastitis therapy performed when a single clot was observed in the milk; 3) clusters rinsed using water or soapy water after milking a cow with high somatic cell count; 4) 305-d milk yield $>7435 \mathrm{~kg}$; 5) herd located in the South region; 6 ) herd located in the North region; 7) cows with at least 1 nonfunctional quarter; and 8) premilking holding area with a slippery surface. The underlying mechanisms of some highlighted risk factors, such as milk production level and dietary management practices, should be investigated more thoroughly through international collaboration.
\end{abstract}

(Key words: clinical mastitis, somatic cell score, dairy management)

Abbreviation key: 36-mo SCS = mean SCS for the 36 mo preceding the beginning of the survey, $\mathbf{C M}=$

Received February 24, 2005.

Accepted June 21, 2005.

Corresponding author: Jacques Barnouin; e-mail: barnouin@ clermont.inra.fr. clinical mastitis, IRCM = incidence rate of clinical mastitis, ZMP = Zero Mastitis Objective program.

\section{INTRODUCTION}

Mastitis is a 2-faceted health problem including subclinical and clinical udder infections. To control IMI status and decrease mastitis (which has negative consequences on animal welfare and economic impact from control costs, penalties, and production losses), 2 main indicators are used in observational and intervention studies: milk SCC and incidence rate of clinical mastitis (IRCM; IDF, 1997). To minimize the occurrence and consequences of herd IMI, a target could be a bulk SCC below 200,000 cells with an IRCM of less than $20 \%$ (Pyörälä, 2003; Schukken et al., 2003).

The very few studies conducted to highlight management factors associated with IRCM in low SCC herds (Schukken et al., 1990; Peeler et al., 2000) indicated a large IRCM variation in this ideal epidemiological situation. A simultaneous evaluation of the risk factors associated with a low SCC and those associated with a lower or higher IRCM is necessary (Barkema et al., 1998), particularly because SCC levels, contrary to IRCM, have fallen over the last 20 yr (Ely et al., 2003; Schukken et al., 2003), whereas the importance of environmental vs. contagious pathogens has increased (Peeler et al., 2003). Nevertheless, if low SCC herds are considered to have higher levels of environmental mastitis (Peeler et al., 2000), clinical mastitis (CM) caused by Staphylococcus aureus has been observed more frequently in herds with a bulk milk cell count lower than 150,000 cells/mL (Elbers et al., 1998).

The main herd risk factors associated with IRCM in low SCC herds (Schukken et al., 1990; Peeler et al., 2000) were: 1) management variables that increased the exposure to environmental pathogens (straw yard housing, poor free stall cleanliness, drinking water from sources other than public water, leaking milk outside the parlor, cleaning the calving area less than once a month, scraping the gathering yard less than twice a day); 2) variables associated with bacterial challenge or host resistance (high percentage of cows leaking milk, postmilking teat disinfection, high frequency of free 
stall disinfection); 3) practices that could be linked to mastitis problems in the herd (wearing of rubber gloves by the dairyman during milking, changing teat liners more frequently); 4) increased detection and reporting of cases of mastitis (stripping foremilk before attaching the clusters); 5) general management practices (long dry period, high replacement rate); 6) genetic and udder conformation dependent traits (breed, milk yield level); and 7) dietary components (sugar beet pulp in the ration). Nevertheless, it is not always easy to clarify whether a factor is cause or effect: for example, farmers may change liners more frequently because of mastitis, or frequent liner changes may potentially damage the teat (Peeler et al., 2000). Moreover, a herd risk factor associated with IRCM could be due to several reasons: a high culling rate could be an indication of one or more of the following: the relevant herd was not stable; the herd size was increasing; there was increased culling for some reason, including mastitis; or that the introduction of cows into an established herd increased the risk of mastitis (Peeler et al., 2000).

Some studies suggested that low SCC was associated with high IRCM (Elbers et al., 1998; Beaudeau et al., 2002; Green et al., 2004), whereas other works did not reveal any interrelationship (Barkema et al., 1998; Beaudeau et al., 1998). These controversial results could depend on: 1) the situation of the herds in terms of prevailing pathogens (Barkema et al., 1998; Peeler et al., 2003); 2) the accuracy of CM evaluation including the epidemiological unit (Gasqui and Barnouin, 2003; Peeler et al., 2003), SCC measurement level (from most to least accurate: quarter, cow, bulk), and length of the period taken to observe CM cases after SCC measurement (Beaudeau et al., 2002); 3) the stability of management practices in the herds; 4 ) the fact that the farmers who are better at diagnosing CM might divert more high SCC milk (Elbers et al., 1998); 5) the observed (negative) association between milk yield level and SCC (Barkema et al., 1998), and (positive association) between milk yield level and CM risk (Schukken et al., 1990; Chassagne et al., 1998).

The purpose of the present epidemiological study was to identify, from a large set of potentially relevant variables, dairy herd management practices and characteristics associated with IRCM in French herds with low SCS fulfilling the following criteria: 1) selected on a national basis from DHIA database; 2) experienced a low SCS over a long period; 3) recorded CM cases through a standardized system, which included individual forms collected monthly; and 4) had a stable dairy management system.

\section{MATERIALS AND METHODS}

\section{General Program}

Data were collected from the Zero Mastitis Objective Program (ZMP), a national mastitis control program carried out in France from February 1999 to July 2001 (Barnouin et al., 2004). The objectives of the ZMP were to display, through several complementary epidemiological studies conducted at herd level, dairy management practices characterizing farms with a high degree of udder health control.

\section{Herd Selection}

The general herd selection procedure of ZMP has been described previously (Barnouin et al., 2004). The surveyed herds were located in 48 French departments, had at least 20 cows of which $90 \%$ were Holstein, Montbéliarde, or Normande breeds, and did not practice vaccination against mastitis. The herd sample was constituted from the National DHIA database according to the herd's previous 36-mo history of somatic cell score (36-mo SCS), because SCS (SCS $=\log _{2}[\mathrm{SCC} / 100,000]$ +3 ) is, contrary to bulk SCC, a criterion not biased by milk discarding. Herd 36-mo SCS was the arithmetic mean of all monthly cow SCS values determined in a herd during the 36 mo preceding ZMP. All the selected herds of the present study had 36-mo SCS that were among the lowest $5 \%$ of SCS for herds within breed, as breed is a key SCS variation factor (Rupp et al., 2000). Consequently, 36-mo SCS was $\leq 1.99$ ( 125,000 cells $/ \mathrm{mL})$ for Montbéliarde herds, $\leq 2.38$ for Holstein herds $(185,000$ cell $\mathrm{s} / \mathrm{mL})$, and $\leq 2.76(230,000$ cell $\mathrm{s} / \mathrm{mL})$ for Normande herds. Three hundred fifty-seven herds were enrolled, representing $15 \%$ of the total number of herds in the National DHIA database that had 36-mo SCS in the lowest $5 \%$. The study did not involve any payment to the selected farmers. Two farmers quit the survey before starting. Five herds were removed because of bovine spongiform encephalopathy. Thirty farmers quit ZMP before it ended for different reasons (DHIA resignation, health problems, lack of time, unknown reasons) or were discarded for incomplete data concerning mastitis recording or questionnaires. Moreover, 23 herds were removed because the farmers did not state the start and end dates of their mastitis recording. In the end, 297 herds were studied, representing $83.2 \%$ of the herds initially enrolled.

\section{Clinical Mastitis}

Clinical mastitis was identified by the farmers based on clinical signs including udder inflammation or abnormal milk, with or without general clinical signs. Farmers were instructed how to fill out a specific record form and required to describe all the observed $\mathrm{CM}$ cases from February 1, 1999 to July 31, 2001. Data included: $\mathrm{CM}$ case definition, cow identification, date of $\mathrm{CM}$ occurrence, clinical description, affected quarters, and treat- 
ment. Data forms were collected and checked monthly by DHIA technicians. To standardize the lag time for a new case, multiple clinical episodes within $8 \mathrm{~d}$ were counted as only 1 case (IDF, 1997). Cow-days at risk were calculated as the total number of days that a cow was present in a herd during the observation period, starting $30 \mathrm{~d}$ before first calving (IDF, 1997), minus 8 $\mathrm{d}$ after each case to correct time at risk for lag time (IDF, 1997). The IRCM was expressed as the reported number of CM episodes during the observation period per 100 cows/yr at risk.

\section{Questionnaire Data}

The DHIA technicians collected questionnaire data concerning characteristics and management practices of the farms by interviewing the farmers. Milk samples were also collected through DHIA to determine milk yield and SCC and other milk quality measures. Bacteriological analyses of milk were not available in the study. The questionnaire variables aimed to describe all aspects of the dairy management system. The questionnaires were validated by consensus of an expert working group and pilot interviews of 10 farmers outside ZMP to check its feasibility and comprehensiveness. Questions not easily understood were excluded. In total, the final version of the questionnaire consisted of 1055 herd characteristics and practices, of which 188 were determined by the technician from preexisting information (farm general descriptors, monthly calving numbers, milking machine characteristics, milk production, and quality data). The interviewees did not have to answer every question because some did not apply to their farm (e.g., free-stall characteristics could not be described when the cows were loose-housed in a straw yard). It required 7 to $8 \mathrm{~h}$ to collect all the questionnaire data. Two complementary questionnaires were administered. The first of these questionnaires, concerning the characteristics of the dairy cow shed and milking parlor, character traits of the herdsman, and measures of milk quality, was carried out from October to December 1999. The second questionnaire, which concerned housing conditions of the herd, the feeding system, udder and calving hygiene, and herd health, was carried out from October to December 2000. Interviewers were the DHIA technicians of the farms studied and they had a thorough knowledge of the herd management system; at the end of the interview, they checked the farmer's answers by requesting confirmation of any information that seemed erroneous. Finally, certain questions concerning 15 herd characteristics and practices, gave rise to answers that were inconsistent with the researchers knowledge of dairy farm management in France. These questions were re- moved from data analyses. The farmers declared at the end of the study that their dairy management system had not changed during ZMP. This statement was checked by the DHIA technicians and we therefore assumed that herd characteristics and practices were stable between the times of the 2 questionnaires.

\section{Database}

All CM and questionnaire data were stored in an Access 2000 (Microsoft France, Courtaboeuf, France) relational database organized through 34 tables. Herd identification number, breed, SCS data, and other milk traits were extracted from the national DHIA database. Checking procedures for data validity were conducted, which consisted of inspecting the CM record forms and questionnaire answers and checking with the interviewer that such answers were normal or incomplete. A set of automatic logical procedures was implemented to detect erroneous entries (e.g., response concerning freestalls if the cows were housed in a straw yard, or number of weeks per year in which the herd was outdoors exceeding $52 \mathrm{wk}$, mastitis clinical cases without any treatment described). Moreover, to check for typing errors, a double keyboard data entry was performed independently by 2 technicians.

\section{Statistical Model}

The association between herd IRCM and potential risk factors was screened using Poisson regression models through the SAS/STAT 8.1 GENMOD procedure (SAS Institute, 1999). Because the variance of IRCM distribution was larger than the mean in the present data, an overdispersed Poisson model with a log link was built (Barkema et al., 1999). With this model, it was assumed that the variance was a constant multiple of the mean instead of equal to the mean (Dohoo et al., 2003). The overdispersion parameter was estimated by the deviance divided by its degrees of freedom. The linearized model used was as follows:

$$
f(N C M)=\alpha+\text { LNDAY }+\beta \mathrm{RF}+\mathrm{e},
$$

where $\mathrm{f}(\mathrm{NCM})=$ link function of herd number of cases (NCM) of clinical mastitis during the observation period, $\alpha=$ intercept, LNDAY = natural log of the number of days of observation in a herd during the observation period, calculated as the sum of days of observation for each present cow (used as an offset variable), $\beta=$ regression coefficient for $\mathrm{RF}, \mathrm{RF}=$ herd risk factor, and $\mathrm{e}=$ Poisson distributed residual random error. Estimated regression coefficients of the model may be expressed exponentially and interpreted as a relative risk or rate ratio. 
Table 1. Variables associated with clinical mastitis at $P \leq 0.25$ included in category models and selected if $P \leq 0.10$ to be in the final Poisson model.

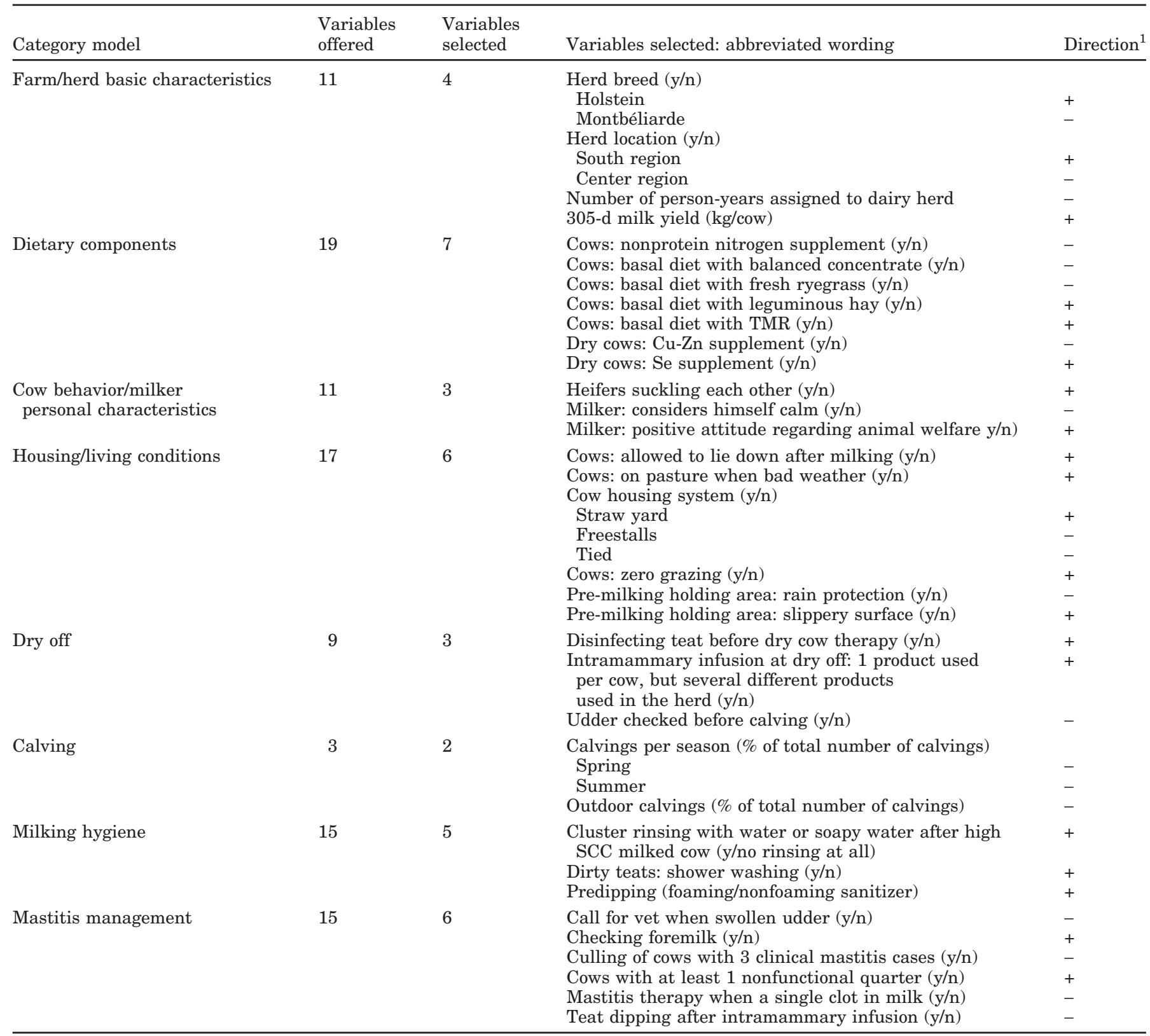

${ }^{1}$ Direction: $+(-)=$ incidence rate of clinical mastitis increased (decreased) if the practice was performed (y). In case of a continuous variable, the incidence rate increased (decreased) with increasing value of the variable.

\section{Modeling Process}

The modeling process included 3 steps. In the first step, all single explanatory variables were screened in a bivariate Poisson model and variables with $P \leq 0.25$ in the likelihood ratio test were selected, as potential candidates for further multiple Poisson regressions. In the second step, the selected variables were grouped within 8 categories of management practices (Table 1). The correlations between the selected variables were analyzed for each category of management practices using the CORR procedure. If variables were correlated (correlation coefficient $>0.15$ or $<-0.15$ ), only the variable with the best fit through the bivariate Poisson model of the first step was included in the corresponding multivariate category model. Consequently, it was reasonable to expect that the multicollinearity between variables was notably weak (Barnouin et al., 2004).

In a last analysis step, variables with $P \leq 0.10$ selected from the 8 category models using backward elimination 


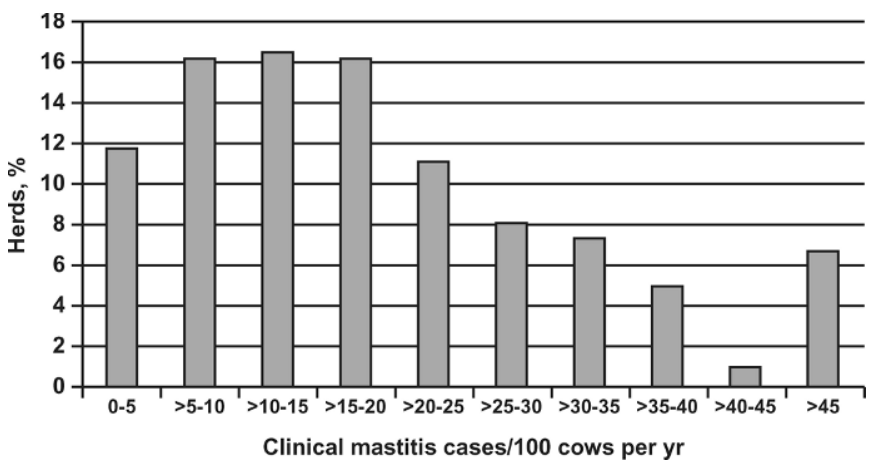

Figure 1. Percentages of low SCS herds with various observed incidence rates of clinical mastitis.

were offered to a final Poisson model. The correlations between the offered variables were analyzed as in the second step. The variables that were significant $(P \leq$ $0.05)$ through the final Poisson model were considered the management variables associated with IRCM. Biologically plausible interactions among significant variables were tested, and none of those interactions was significant. The goodness of fit of the model was assessed by standardized deviance residual analysis (McCullagh and Nelder, 1989). Moreover, the Grubbs' test (Grubbs, 1969) was used to detect potential outliers.

\section{RESULTS}

\section{Herd Characteristics}

The average total area of the ZMP dairy farms was 76.1 ha $(\mathrm{SD}=38.8)$ including 53.6 ha $(\mathrm{SD}=27.3)$ of forage area. The average number of cows was $41.4(\mathrm{SD}=$ 14.5). Sixty-four percent of herds had Holstein cows, $31 \%$ had Montbéliarde cows, and 5\% had Normande cows. The average percentage of primiparous was $31.2 \%(\mathrm{SD}=5.1)$. Mean milk yield was $7420 \mathrm{~kg} / \mathrm{cow}$ per yr $(\mathrm{SD}=968)$, and mean protein and fat contents were $3.2 \%(\mathrm{SD}=1.1)$ and $4.1 \%(\mathrm{SD}=2.6)$, respectively. Mean milk SCS was 2.04 ( $\mathrm{SD}=0.26$ ), which corresponded to 132,000 cells $/ \mathrm{mL}$. Average percentages of monthly SCC $<50,000$ cells $/ \mathrm{mL},>300,000$ cells $/ \mathrm{mL}$, and $>800,000$ cells $/ \mathrm{mL}$ were $54.3 \%(\mathrm{SD}=9.5), 8.1 \%(\mathrm{SD}=3.6)$ and $2.7 \%(\mathrm{SD}=1.6)$, respectively. Moreover, the farmers declared that their current herd SCC level had been of the same order for $7.9 \mathrm{yr}$ on average $(\mathrm{SD}=4.2)$.

\section{Clinical Mastitis}

A total of $5022 \mathrm{CM}$ cases covering 20,084 cows and 37,393 lactations were observed during the program. The average IRCM was 20.1 cases $/ 100$ cows per yr (SD = 16.1). This ranged from 0 to 116 . Distribution of IRCM per herd is presented in Figure 1. The IRCM was lower than 20 cases $/ 100$ cows per yr in $60 \%$ of the surveyed herds and higher than 40 cases/100 cows per yr in $8 \%$ of the studied herds.

\section{Regression Analysis}

A total of 191 variables were significantly associated with IRCM in the first analysis step. From these variables, 91 were removed because they were correlated. Among the 100 variables that were offered to the 8 category models (Table 1), 36 were selected for the final Poisson model. These variables, their description, and the direction of their association with IRCM are shown in Table 1. The final model (Table 2) included 10 management and herd characteristic variables. The deviance was 1609.04 on $278 \mathrm{df}$. The estimated overdispersion parameter from the sample mean and variance was 2.43. The model showed a good fit to the data: the standardized deviance residuals of the model displayed no obvious patterns (Figure 2), and the Grubbs' test did not reject the hypothesis of no outliers, the observed $G$ value (2.916) being lower than the critical value (3.675).

From the final model (Table 2), herds with the following characteristics had lower IRCM: a) culling of cows when more than $3 \mathrm{CM}$ cases occurred within a lactation $(P \leq 0.001)$; b) more than 2 person-years assigned to dairy herd management; c) balanced concentrate in the cow basal diet (b to c: $P \leq 0.01$ ). Herds with the following characteristics had higher IRCM: a) milking cows loosehoused in a straw yard; b) no mastitis therapy performed when a single clot was observed in the milk (a to b: $P \leq 0.001$ ); c) clusters rinsed using water or soapy water after a high SCC milked cow; d) 305-d milk yield $>7435 \mathrm{~kg}$; e) herd located in the South region; f) herd located in the North region (c to f: $P \leq 0.01$ ); g) cows with at least 1 nonfunctional quarter; h) premilking holding area with a slippery surface ( $\mathrm{g}$ to $\mathrm{h}: P \leq 0.05$ ). Moreover, 23 variables removed from the statistical analysis were correlated with the significant variables of the final model (Table 3). The highest positive correlation coefficients $(>0.400)$ concerned the following variables: West region and fresh ryegrass in the diet, 305$\mathrm{d}$ milk yield and percentage of corn area, cow tie-stall housing system and Montbéliarde breed, and East region and farm altitude. The highest negative correlation coefficients $(<-0.400)$ concerned: West region and farm altitude, cow tie-stall housing system and cow shed with a special area for dry cows, and tie-stall housing system and Holstein breed.

\section{DISCUSSION}

The ZMP is the first epidemiological work that aimed to highlight herd variables associated with CM risk 
Table 2. Final Poisson model for outcome variable clinical mastitis $(\mathrm{n}=297)$ : parameter $(\beta)$, standard error, probability, rate ratio (RR), and percentage of herds with the practice or characteristic (\%). The scaled deviance was 1609.04 on $278 \mathrm{df}$.

\begin{tabular}{|c|c|c|c|c|c|}
\hline Variable & $\beta$ & $\operatorname{SE}(\beta)$ & $P$ & $\mathrm{RR}$ & $\%$ \\
\hline Intercept & -7.724 & 0.208 & $<0.0001^{* * *}$ & - & - \\
\hline Culling of cows with 3 clinical mastitis cases & -0.328 & 0.073 & $<0.0001^{* * *}$ & 0.720 & 56.27 \\
\hline More than 2 person-years assigned to dairy herd & -0.231 & 0.077 & $0.0028 * *$ & 0.794 & 37.04 \\
\hline Cow basal diet with balanced concentrate & -0.200 & 0.071 & $0.0050 * *$ & 0.819 & 53.56 \\
\hline Cows with at least 1 nonfunctional quarter & 0.190 & 0.076 & $0.0121 *$ & 1.209 & 58.92 \\
\hline Premilking holding area: slippery surface & 0.226 & 0.094 & $0.0162 *$ & 1.254 & 13.47 \\
\hline No mastitis therapy when a single clot in milk & 0.276 & 0.073 & $0.0001 * * *$ & 1.318 & 30.17 \\
\hline Cluster rinsing after high SCC milked cow & 0.335 & 0.089 & $0.0002^{* *}$ & 1.398 & 14.58 \\
\hline \multicolumn{6}{|l|}{ Cows: housing system } \\
\hline Freestalls & - & - & - & 1 & 48.82 \\
\hline Tied & -0.106 & 0.153 & NS & 0.900 & 14.14 \\
\hline Straw yard & 0.318 & 0.077 & $<0.0001^{* * *}$ & 1.374 & 37.04 \\
\hline \multicolumn{6}{|l|}{ Herd location } \\
\hline Center & - & - & - & 1 & 15.15 \\
\hline West & 0.088 & 0.135 & NS & 1.092 & 21.21 \\
\hline East & 0.245 & 0.126 & NS & 1.278 & 40.40 \\
\hline North & 0.380 & 0.146 & $0.0093^{* *}$ & 1.463 & 9.77 \\
\hline South & 0.422 & 0.145 & $0.0037 * *$ & 1.524 & 13.47 \\
\hline \multicolumn{6}{|l|}{ 305-d milk yield (kg) } \\
\hline$<6705$ & - & - & - & 1 & 25.92 \\
\hline$\geq 6705$ to $\leq 7435$ & 0.060 & 0.120 & NS & 1.062 & 24.58 \\
\hline$\geq 7435$ to $\leq 8130$ & 0.294 & 0.113 & $0.0096^{* *}$ & 1.341 & 24.58 \\
\hline$>8130$ & 0.298 & 0.111 & $0.0071^{* *}$ & 1.347 & 24.92 \\
\hline
\end{tabular}

$* * * P \leq 0.001 ; * * P \leq 0.01 ; * P \leq 0.05 ; \mathrm{NS}=P>0.05$.

using SCS to select, on a national basis, a sample of herds having "low" SCS for at least $5 \mathrm{yr}$ and a stable dairy management system (Barnouin et al., 2004). Nevertheless, SCC levels considered "low" can differ among countries. An adequate between-country comparison must include the same SCC criterion, which can be

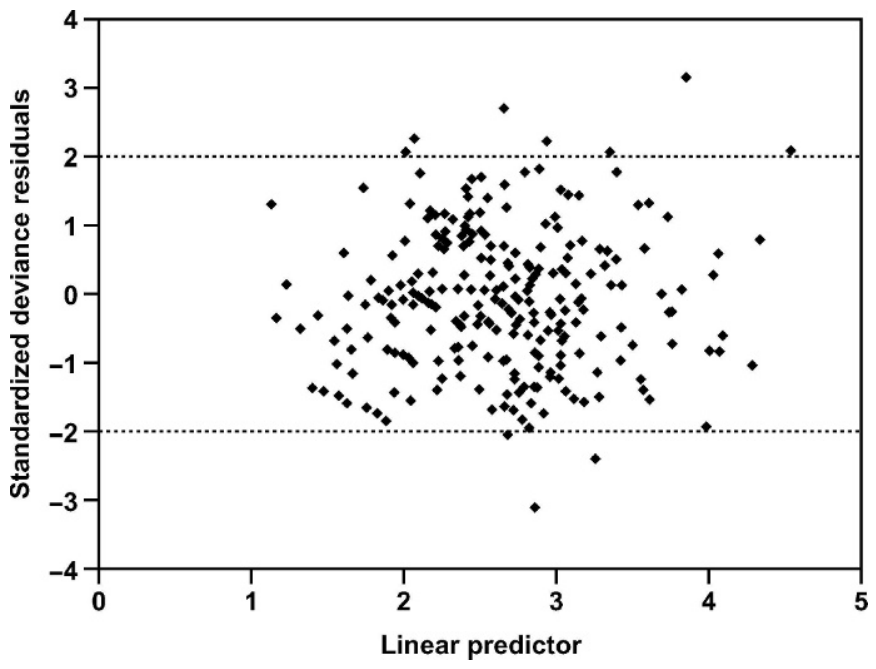

Figure 2. Plot of standardized deviance residuals vs. linear predictor for the model shown in Table 2. The final model included 10 management and herd characteristics associated with the incidence of clinical mastitis. No obvious patterns were observed, consistent with a good fit of the model. biased by milk discarding. Concerning CM, some cases would probably not have been reported by the farmers. Nevertheless, the monthly farm visits conducted by the surveyors, which included a systematic checking of any reported case, would have contributed to improvements in case reporting.

The present study aimed to test many management characteristics. Consequently, an effort was made through study design and statistical procedure to reduce the multicollinearity among explanatory variables, a relatively frequent situation within the dairy management system. The categorization of risk factors was performed to facilitate the detection of interrelated management practices, although categorization is often subjective (Schukken et al., 1990). To lower the collinearity among explanatory variables, a set of correlated variables was removed from the analysis according to statistical reasons. As items for discussion, we summarized (Table 3 ) the variables that were removed because they were correlated with the significant variables of the final model. Nevertheless, the fact that a model fits does not ensure the model contains the best biological information. Moreover, in epidemiological studies, the observed association between a factor and a disease did not display an obviously causal relationship (Schukken et al., 1990). But most of the time, it is difficult to conduct rigorous intervention studies on private farms to demonstrate the true relationship between herd 
Table 3. Variables correlated (correlation coefficient $>0.150$ or $<-0.150$ ) with the variables of the final Poisson model.

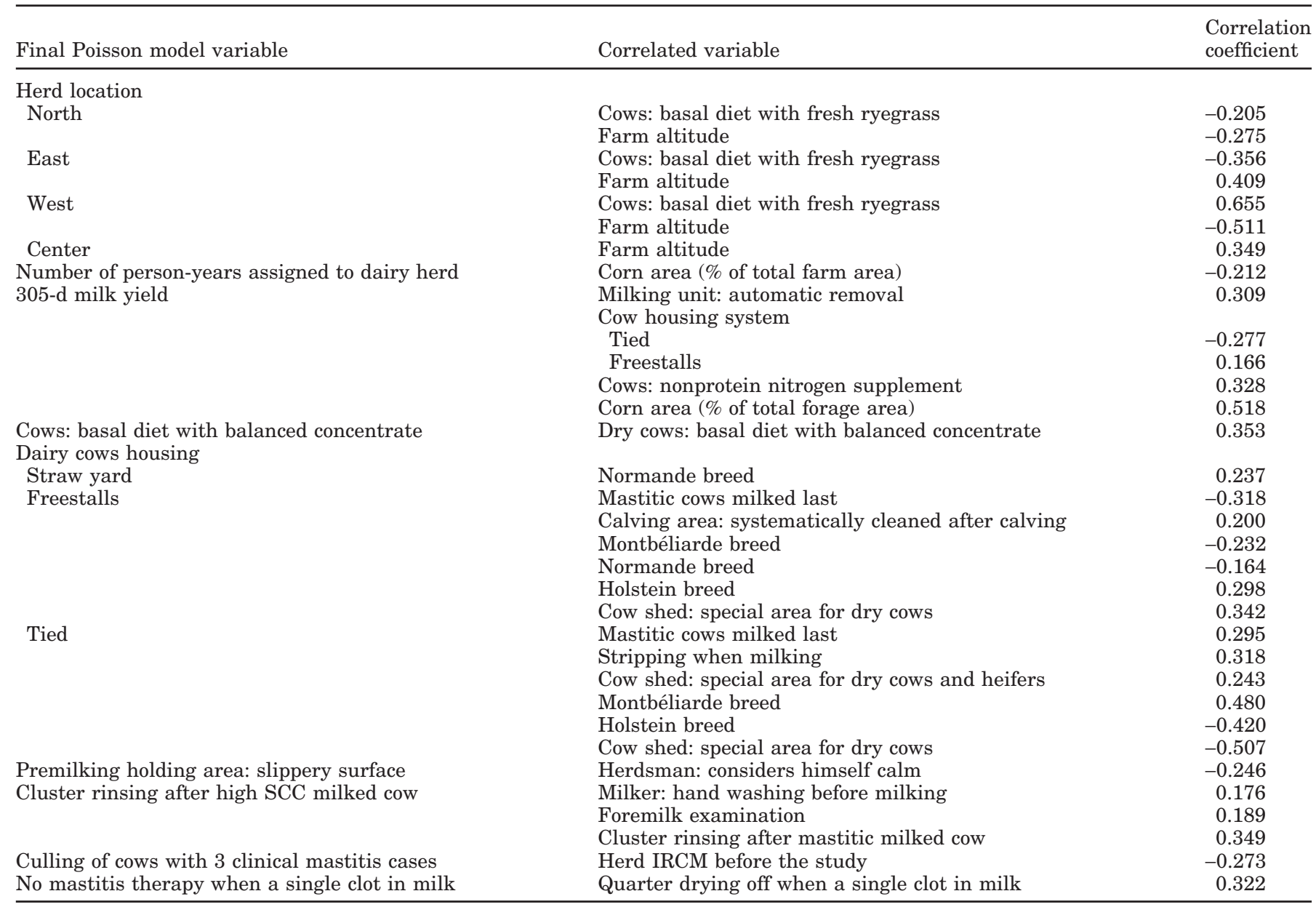

management practices and mastitis risk, as has, nevertheless, been implemented by Lam et al. (1997).

From previous ZMP results (Barnouin et al., 2004), 18 major variables allowed discrimination between very low and medium SCS herds, whereas 10 variables were associated with IRCM in the very low SCS herds of the present study. Two variables, which both characterized medium SCS herds vs. low SCS herds and were associated with IRCM in the present study, appeared as mastitis risk factors: 1) milking cows loose-housed in a straw yard; and 2) no mastitis treatment when a single clot was observed in milk at successive milking. Moreover, 2 variables were risk factors for 2 epidemiological situations: 1) cows culled when found with at least 1 damaged teat characterized low SCS herds, whereas cows culled after 3 clinical cases within a lactation characterized low SCS herds that had lower IRCM; and 2) less than 1 person assigned to extra dairy management activities characterized low SCS herds, whereas more than 2 persons assigned to dairy management characterized low SCS herds that had lower IRCM.
Concerning the housing system, which was correlated with numerous variables in the present study (Table 3 ), our results agree with those of Peeler et al. (2000), who demonstrated that straw yards resulted in a significant increase in IRCM in low SCC herds. In a study of the incidence of CM in straw yards and freestalls, Fregonesi and Leaver (2001) found less CM cases in freestalls. Straw is a bedding material favoring rapid growth of the main udder pathogens, particularly in humid weather conditions and in bedding kept moist through urine excretion (Ward et al., 2002). As a major part of the udder environment, hygiene and bedding play an important role in the transmission of environmental pathogens implicated in CM (mainly $E$. coli and Strep. uberis), but also in the development of contagious pathogens (mainly Staph. aureus) with subsequent CM and subclinical cases (Elbers et al., 1998). Moreover, recurrent $\mathrm{CM}$ episodes with a transient subclinical stage and caused by $E$. coli through transmission from one quarter to another, could contribute significantly to increased IRCM in low SCC herds (Döpfer et al., 
1999), in which $E$. coli is considered the predominant pathogen causing CM (Barkema et al., 1998).

Regional differences in SCS have been shown previously in the United States (Miller et al., 1999; Ely et al., 2003) and variation in CM risk in France could depend on meteorological factors (Barnouin et al., 1986). Through the present study, the herds that were located in the North and in the South regions have been shown to have a higher IRCM. In France, these 2 regions are less specialized in bovine production than the West, East, and Center regions. Consequently, fewer well-trained dairy management experts would serve in the North and South regions (Chassagne et al., 2005). Nevertheless, as fresh ryegrass in the diet and farm altitude were correlated with herd location in the present study (Table 3), some other undetermined reasons could explain the observed regional differences in $\mathrm{CM}$ risk.

In ZMP, the presence of a single clot observed in the milk was not considered a mastitis case by herdsmen. Nevertheless, CM therapy was practiced in some farms after observation of a single clot to prevent mastitis. As IRCM were higher in the farms in which such a practice was not performed, the presence of a single clot in the milk could be considered a precursory signal that would precede CM occurrence. Actually, early treatment of mastitis reduced the severity of the disease and more easily brought about a bacteriological cure (Milner et al., 1997). In particular, early intervention using an intramammary antibiotic would achieve a cure for all infections caused by Strep. uberis (Hillerton and Semmens, 1999). Although changes in the milk electrical conductivity and biochemical indicators can help detect early udder infection (Milner et al., 1997), none of the automatic detection methods is, at present, satisfactory, and false alerts are frequent (Pyörälä, 2003). The ZMP results would indicate that a conventional detection method based on identification of clots by the milker could be an effective way to prevent $\mathrm{CM}$ and SCM when treatment is initiated after observation of a single clot. However, to be able to control CM, farmers with low SCS herds must be trained not only to detect clots, but also to treat cows efficiently and hygienically (Barnouin et al., 2004), and to separate them from the rest of the herd to reduce spreading contaminated milk from infected to healthy cows.

Culling a cow with $3 \mathrm{CM}$ occurrences within a lactation, that is, within a relatively short time of first becoming infected, would limit the transmission of potentially invasive bacteria able to cause CM (White et al., 2003). Moreover, this practice could have a CM-reducing effect by removing cows that might give rise to cases in the future. The influence on IRCM of such a culling measure, which might depend on the pathogen that caused the CM, has not been previously studied in epidemiological surveys conducted in low SCC herds. Through ZMP, culling practices would be effective to decrease mastitis risk in 2 different ways, as culling cows with damaged teats characterized low SCC herds (Barnouin et al., 2004), whereas culling cows with multiple cases of CM within a lactation was associated with a lower CM risk in the present study.

According to Barnouin et al. (2004), herdsmen must be specialized in dairy farming for long-term control of herd SCS. To decrease IRCM in low SCS farms, at least 2 person-years, in addition to herd specialization, must be assigned to dairy management in French farming conditions, including smaller herd sizes than in some countries. Extra persons are needed because adequate and permanent CM detection, treatment, and management of treated animals require much more time than for herd SCC management. Interaction between the cowman and his animals would define a competent dairy farmer, the regularity of contact being important to develop and maintain satisfactory human-animal interactions (Raussi, 2003). Such satisfactory contacts would decrease stressful breeding conditions, reduce udder injuries, and avoid stress-dependent alteration in immune responsiveness (Cai et al., 1994). Moreover, in low SCC herds, Holtenius et al. (2004) suggested that there were differences in the metabolism and immune status between herds with high or low mastitis incidence indicating increased metabolic stress in highincidence herds. Finally, frequent contacts between herdsmen, technicians, and cows would promote quick therapeutic decisions following any change in udder or milk appearance, and would favor accurate mastitis control (Barnouin et al., 2004).

A premilking holding area with a slippery surface, which was displayed as a risk factor for CM, could increase udder injuries and stress, with consequences as previously discussed. Avoiding slippery holding areas is a recommended practice in some DHIA and prevention programs, but such a practice was not previously displayed as characterizing very low mastitis risk herds. Moreover, in the high IRCM herds, the clusters were more frequently rinsed using water or soapy water after a cow with a high SCC. The farmers in the present study, as good dairy managers, tried to reduce risk of CM through cluster rinsing when a high SCC was determined exceptionally in a cow of their low SCC herd. Such a practice did not affect the incidence of staphylococcal, streptococcal, and gram-negative bacterial infections, and clinically infected quarters (Smith et al., 1985). Cluster rinsing leads only to a marginal reduction of bacterial load, whether using water or disinfectant (Shearn et al., 1994). 
A basal diet containing a commercial concentrate with a balanced energy/protein ratio could contribute, especially in the early lactation, to fewer metabolic disorders that could be linked to risk of mastitis (Holtenius et al., 2004). In low SCC cows, sugar beet pulp as concentrate was associated with a higher IRCM (Schukken et al., 1990), whereas Johnson and Otterby (1981) found higher energy supplies at drying-off in dairy cows that subsequently developed CM. Dietary polyunsaturated fatty acid levels could modulate the leukocyte activity in the milk and inflammation in the udder (Barnouin et al., 1995). Consequently, adequate energy supplies through basal diet and concentrate could be protective factors against CM risk in low SCC herds, although a clear explanation of the etiological mechanism is not available. From the results of ZMP, higher milk production was associated with a high IRCM. Interestingly, this variable also characterized high IRCM herds through univariate (Schukken et al., 1990) or multivariate (Peeler et al., 2000) statistical analyses concerning CM factors in low SCC farms. For Peeler et al. (2000), the risk threshold for an increased CM risk was 7500 $\mathrm{kg} / \mathrm{cow}$ per yr, similar to current results $(7436 \mathrm{~kg})$. The positive association between milk yield level and CM risk was previously demonstrated in French Holstein herds at the cow level (Chassagne et al., 1998), and such a relationship was found in a study conducted in Ontario Holstein herds (Bigras-Poulin et al., 1990). Through the present study, a high correlation has been displayed between milk yield level and importance of corn as a forage (Table 3), a feedstuff high in calories but rather poor in several amino acids, minerals, trace elements, and vitamins. Moreover, 8 different dietary components, displayed in Tables 1 and 3 as variables selected at the first analysis step or correlated with the significant variables of the final model, might indicate that the relationship between dietary components and CM risk should be more deeply investigated in low SCC herds. Some management practices commonly related to $\mathrm{CM}$ risk were not associated with the disease in the present study. In the present study, vaccination against mastitis was not performed in the herds, nor was the use of internal sealants. Moreover, dry cow environment, milking technique, teat dipping, and calving conditions were associated in ZMP to subclinical mastitis risk (Barnouin et al., 2004; Chassagne et al., 2005).

In countries where intensive breeding conditions seem the only way to produce milk profitably, increased CM risk through high milk production could be considered as part of the natural cost of production, as is concentrate feeding or $3 \times$ milking in high output herds (Chassagne et al., 1998). Nevertheless, genetic, metabolic, conformation, and behavioral evaluations should be conducted in high-yielding and very low SCC herds to evaluate if production level and CM traits are definitively antagonistic through the udder, an organ so delicate and sensitive, but also efficient. Such studies should focus on clinical cases during the postpartum period and consider dairy management practices characterizing very low mastitis risk from ZMP (Barnouin et al., 2004) and from other mastitis control programs conducted in low SCC herds (Schukken et al., 1990; Peeler et al., 2000). Such studies could profitably involve scientific collaborations including epidemiological studies implemented at the multicountry level and be a further step for a better understanding of mastitis.

\section{ACKNOWLEDGMENTS}

Very sincere thanks to all the farmers and staff members of DHIA and other organizations for their tremendous motivation and expertise. This research was partially funded by Schering Plough Vétérinaire (Paris, France) and did not involve any specific payment to the selected herdsmen and technicians.

\section{REFERENCES}

Barkema, H. W., Y. N. Schukken, T. J. G. M. Lam, M. L. Beiboer, G. Benedictus, and A. Brand. 1998. Management practices associated with low, medium, and high somatic cell counts in bulk milk. J. Dairy Sci. 81:1917-1927.

Barkema, H. W., Y. H. Schukken, T. J. G. M. Lam, M. L. Beiboer, G. Benedictus, and A. Brand. 1999. Management practices associated with the incidence rate of clinical mastitis. J. Dairy Sci. 82:1643-1654.

Barnouin, J., M. Chassagne, and I. Aimo. 1995. Dietary factors associated with milk somatic cell counts in dairy cows in Brittany, France. Prev. Vet. Med. 21:299-311.

Barnouin, J., M. Chassagne, S. Bazin, and D. Boichard. 2004. Management practices from questionnaire surveys in herds with very low somatic cell score through a national mastitis program in France. J. Dairy Sci. 87:3989-3999.

Barnouin, J., J. C. Fayet, M. Jay, M. Brochart, and B. Faye. 1986. Enquête éco-pathologique continue: Facteurs de risque des mammites de la vache laitière. II. Analyses complémentaires sur données individuelles et d'élevage. Can. Vet. J. 27:173-184.

Beaudeau, F., C. Fourichon, H. Seegers, and N. Bareille. 2002. Risk of clinical mastitis in dairy herds with a high proportion of low individual milk somatic cell-count. Prev. Vet. Med. 53:43-54.

Beaudeau, F., H. Seegers, C. Fourichon, and P. Hortet. 1998. Association between milk somatic cell counts up to 400,000 cells $/ \mathrm{mL}$ and clinical mastitis in French Holstein cows. Vet. Rec. 143:685-687.

Bigras-Poulin, M., A. H. Meek, and S. W. Martin. 1990. Interrelationship among health problems and milk production from consecutive lactations in selected Ontario Holstein cows. Prev. Vet. Med. 8:15-24.

Cai, T. Q., P. G. Wesron, L. A. Lund, B. Brodie, D. J. McKenna, and W. C. Wagner. 1994. Association between neutrophil functions and periparturient disorders in cows. Am. J. Vet. Res. 55:934-943.

Chassagne, M., J. Barnouin, and J. P. Chacornac. 1998. Biological predictors for clinical mastitis occurrence in Holstein cows under field conditions in France. Prev. Vet. Med. 35:29-38.

Chassagne, M., J. Barnouin, and M. Le Guenic. 2005. Expert assessment study of milking and hygiene practices characterizing very low somatic cell score herds in France. J. Dairy Sci. 88:1909-1916.

Dohoo, I., W. Martin, and H. Stryhn. 2003. Veterinary epidemiologic research. AVC Inc., Charlottetown, Prince Edward Island, Canada. 
Döpfer, D., H. W. Barkema, T. J. G. M. Lam, Y. H. Schukken, and W. Gaastra. 1999. Recurrent clinical mastitis caused by Escherichia coli in dairy cows. J. Dairy Sci. 82:80-85.

Elbers, A. R. W., J. D. Miltenburg, D. De Lange, A. P. P. Crauwels, H. W. Barkema, and Y. H. Schukken. 1998. Risk factors for clinical mastitis in a random sample of dairy herds from the southern part of The Netherlands. J. Dairy Sci. 81:420-426.

Ely, L. O., J. W. Smith, and G. F. Oleggini. 2003. Regional production differences. J. Dairy Sci. 86(E Suppl.):E28-E34.

Fregonesi, J. A., and J. D. Leaver. 2001. Behaviour, performance and health indicators of welfare for dairy cows housed in strawyard or cubicle systems. Livest. Prod. Sci. 68:205-216.

Gasqui, P., and J. Barnouin. 2003. Statistical modelling for clinical mastitis in the dairy cow: Problems and solutions. Vet. Res. 34:493-506.

Green, M. J., P. R. Burton, L. E. Green, Y. H. Schukken, A. J. Bradley, E. J. Peeler, and G. F. Medley. 2004. The use of Markov chain Monte Carlo for analysis of correlated binary data: Patterns of somatic cells in milk and the risk of clinical mastitis in dairy cows. Prev. Vet. Med. 64:157-174.

Grubbs, F. 1969. Procedures for detecting outlying observations in samples. Technometrics 11:1-21.

Hillerton, J. E., and J. E. Semmens. 1999. Comparison of treatment of mastitis by oxytocin or antibiotics following detection according to changes in milk electrical conductivity prior to visible signs. J. Dairy Sci. 82:93-98.

Holtenius, K., K. P. Waller, B. Essen-Guvtavsson, P. Holtenius, and P. Sandgreen. 2004. Metabolic parameters and blood leukocyte profiles in cows from herds with high or low mastitis incidence. Vet. J. 168:65-73.

IDF. 1997. Recommendations for presentation of mastitis-related data. Bull. 321, Int. Dairy Fed., Brussels, Belgium.

Johnson, D. G., and D. E. Otterby. 1981. Influence of dry period on early postpartum health, feed intake, milk production and reproductive efficiency. J. Dairy Sci. 64:290-295.

Lam, T. J. G. M., J. H. van Vliet, Y. H. Schukken, F. J. Grommers, A. van Velden-Russcher, H. W. Barkema, and A. Brand. 1997. The effect of discontinuation of post milking teat disinfection in low somatic cell count herds. I. Incidence of clinical mastitis. Vet. Q. 19:41-47.

McCullagh, P., and J. A. Nelder. 1989. Generalized linear models. D. R. Cox, D. V. Hinkley, D. Rubin, and B. W. Silverman, ed. Chapman and Hall, London, UK.

Miller, R. H., H. D. Norman, G. R. Wiggans, and J. R. Wright. 1999. National survey of herd somatic cell counts on DHI test days.
Pages 161-162 in Proc. Natl. Mastitis Council Annu. Mtg.. National Mastitis Council, Madison, WI.

Milner, P., K. L. Page, and J. E. Hillerton. 1997. The effects of early antibiotic treatment following diagnosis of mastitis detected by a change in the electrical conductivity of milk. J. Dairy Sci. 80:859-863.

Peeler, E. J., M. J. Green, J. L. Fitzpatrick, and L. E. Green. 2003. The association between quarter somatic-cell counts and clinical mastitis in three British dairy herds. Prev. Vet. Med. 59:169-180.

Peeler, E. J., M. J. Green, J. L. Fitzpatrick, K. L. Morgan, and L. E. Green. 2000. Risk factors associated with clinical mastitis in low somatic cell count British dairy herds. J. Dairy Sci. 83:2464-2472.

Pyörälä, S. 2003. Indicators of inflammation in the diagnosis of mastitis. Vet. Res. 34:565-578.

Raussi, S. 2003. Human-cattle interactions in group housing. Appl. Anim. Behav. Sci. 80:245-262.

Rupp, R., D. Boichard, C. Bertrand, and S. Bazin. 2000. Bilan national des numérations cellulaires dans le lait des différentes races bovines laitières françaises. INRA Prod. Anim. 13:257-267.

SAS Institute. 1999. SAS User's Guide. Statistics. Version 8 ed. SAS Inst., Inc., Cary, NC.

Schukken, Y. H., F. J. Grommers, D. van de Geer, H. N. Erb, and A. Brand. 1990. Risk factors for clinical mastitis in herds with a low bulk milk somatic cell count. 1. Data and risk factors for all cases. J. Dairy Sci. 73:3463-3471.

Schukken, Y. H., D. J. Wilson, F. Welcome, L. Garrson-Tikofsky, and R. N. Gonzalez. 2003. Monitoring udder health and milk quality using somatic cell counts. Vet. Res. 34:579-596.

Shearn, M. F. H., J. Morgan, and J. E. Hillerton. 1994. Reduction of bacterial contamination of teatcup liners by an entrained wash system. Vet. Rec. 134:450.

Smith, T. W., R. J. Eberhart, S. B. Spencer, E. M. Kesler, G. L. Hargrove, R. W. Wilson, and C. W. Heald. 1985. Effect of automatic backflushing on number of new intramammary infections, bacteria on teatcup liners, and milk iodine. J. Dairy Sci. 68:424-432.

Ward, W. R., J. W. Hughes, W. B. Faull, P. J. Cripps, J. P. Sutherland, and J. E. Sutherst. 2002. Observational study of temperature, moisture, $\mathrm{pH}$ and bacteria in straw bedding, and faecal consistency, cleanliness and mastitis in four dairy herds. Vet. Rec. 151:199-206.

White, L. J., T. J. G. M. Lam, Y. H. Schukken, L. E. Green, G. F. Medley, and M. J. Chapell. 2003. The transmission of clinical and subclinical mastitis in dairy cows: A theoretical approach. Proc. Soc. Vet. Epidem. Prev. Med., Warwick, UK. 